\title{
The Normal Radiographic Anatomy of the Forelimb in Sunda Porcupine
}

$$
\text { (ANATOMI RADIOGRAFI NORMAL PADA KAKI DEPAN LANDAK JAWA) }
$$

\author{
Yuliani Suparmin $^{1 *}$, Gunanti $^{1}$, Deni Noviana ${ }^{1,2}$, Srihadi Agungpriyono ${ }^{3}$ \\ ${ }^{1}$ Department of Veterinary Clinic Reproduction and Pathology, IPB University, Jl. Agatis, \\ Kampus IPB Dramaga Bogor 16680, Indonesia; \\ ${ }^{2}$ IPB Veterinary Teaching Hospital, IPB University, Jl. Agatis, Kampus IPB Dramaga Bogor \\ 16680, Indonesia; \\ ${ }^{3}$ Department of Anatomy, Physiology and Pharmacology, IPB University, Jl. Agatis, Kampus \\ IPB Dramaga Bogor 16680, Indonesia. \\ *Email: yulianisuparmin01@gmail.com
}

\begin{abstract}
The aim of this project is to develop a detailed accessible set of reference images of the normal forelimb radiographic anatomy in sunda porcupine (Hystrix javanica), including digit,carpus, metacarpal, radius, ulna, and humerus. This project that using 2 healthy sunda porcupines (male and female) was radiograped using digital radiography and standars projection. Four images, illustrating the normal radiographic anatomy of the forelimb were selected and presented along with detailed description. These image are aimed to be of assistence to veterinary surgeons, veterinary students, medic concervation especially in domestic wild animal, and veterinary researchers by enabling understand of the normal radiographic anatomy of the forelimb, and allowing comparison with the abnormal radiographic.
\end{abstract}

Keywords: Anatomy, forelimb, radiograph, sunda porcupine

\begin{abstract}
Abstrak
Tujuan dari penelitian ini adalah untuk mengembangkan referensi anatomi radiografi kaki depan landak jawa (Hystrix javanica) yang terdiri dari digit, carpus, metacarpal, radius, ulna, dan humerus. Penelitian ini menggunakan 2 ekor landak jawa (jantan dan betina) menggunakan mesin radiografi digital dan proyeksi standar. Empat gambar menggambarkan radiografi normal kaki depan dan dideskripsikan secara rinci. Gambar ini berguna untuk membantu para ahli bedah, mahasiswa kedokteran hewan, medik konservatif khususnya hewan domestik, dan para peneliti dengan pemahaman anatomi radiografi normal kaki depan, dan memungkinkan perbandingan dengan radiogafi yang abnormal.
\end{abstract}

Kata-kata kunci: Anatomi, kaki depan, radiografi, landak jawa.

\section{INTRODUCTION}

Indonesia is known as the second largest biodiversity country (megabiodiversitas) in the world after Brazil (KKP, 2015). Recognizing the magnitude of Indonesia's biodiversity, efforts need to be made to safeguard and protect its sustainability. This is because biodiversity has an important role in maintaining ecosystem stability, as a source of germplasm and economic resources (KKP, 2015). Therefore, the Ministry of
Environment and Forestry (KLHK) has recently issued a regulation Number P.20/MENLHK/SETJEN/KUM.1/6/2018 concerning protected species of plants and animals. The regulation was issued as a form of protection against endangered animals, one of which is sunda porcupine (Hystrix javanica).

Sunda porcupine is fossorial animal, so when looking for food, they often use their front legs to dig in the soil, which anatomically involves active motion, both 
the forelimg and hindlimb. Adaptation and the ability of sunda porcupine to defend themselves and dig holes in the ground need to be supported by anatomical structures that can support their activities, one of which is bone. Bones are a part of the body that has many functions including the formation of the body's frame, a place for storing calcium and in the long bones there is a bone marrow that has pluripotent properties that can produce cells for the body. This makes bones and joints an important part of the body, so that damage to bones and joints can disrupt the balance and running of processes in the body (Thompson, 2004). The role of bones and joints is very high in supporting the body (Rahmah et al., 2017).

In addition to macroanatomic observations, bone shape can be identified through radiographic examination. Radiographic examination is a noninvasive diagnostic technique that is highly recommended in wildlife and can be used in developing wildlife management and conservation strategies (Galateanu et al., 2014). The principle of digital radiography is to utilize the difference in X-ray absorption in parts of bone and other tissues (Kotter, 2002). Taking X-rays is to determine bone shape and confirm diagnosis (IQWiG, 2006).

To recognize abnormalities of radiographic images effectively, understanding normal radiographic anatomy in a specific area is very necessary (Davies dan Pettersson, 2002; Thrall and Robertson, 2010). Diagnostic imaging in pets has a lot of data supported by a large number of subjects examined. However it is different from wild animals whose data is still minimal. The use of data in diagnostic imaging in wild animals often uses radiographic data on domestic animals that have been widely used. The lack of radiographic data on wild animals is caused by the lack of radiographic research carried out so that this is one of the challenges faced in the medical aspect, especially wildlife (Galateanu et al., 2014).
Knowledge of radiographic anatomical structure is very important and is a basic knowledge for identifying species and interpretive goals in an effort to increase endemic wildlife preservation because it can help veterinarians in the clinical aspect (Makungu et al., 2013; Schimming et al., 2015; Mohamed, 2018). To obtain an accurate diagnosis of radiographic images, knowledge of the normal radiographs of the structures examined is needed (Duncan et al., 2013). However, the normal radiographic anatomy of the forelimb of sunda porcpine has never been done. Information obtained can be used to assist in detecting, diagnosing, and treating abnormalities or abnormalities of the forelimb, as well as the basis for further research on sunda porcupine and other similar species.

\section{MATERIALS AND METHODS}

This research has got agreement ethical approval from animal ethics commision on research institution and community service (KEH-LPPM) IPB on Number 130-2018 IPB. This research is using 2 samples sunda porcupine (Hystrix javanica) male and female with an estimated age of 6 months and 2 years. The sunda porcupine is obtained from the catches in wildlife in accordance with the permission of the Director General of Natural Resource Conservation and the Ecosystem, Ministry of Enviroment anf Forestry on Number SK. 386/KSDAE/SET/KSA.2/ 10/2017. This research was conducted in JanuaryFebruary 2019 at the My Vets Animal Clinic Bumi Serpong Damai (BSD) in South Tangerang.

The tools and materials used in this research are digital X-ray machines (Indoray IKL-17E-100/24, PT. Poly Jaya Medical), x-ray flat panel detectors (CareView 1800L, CareRay Medical Systems Co.), clamp enclosures made of iron measuring 45×26×26 cm, syringe $1 \mathrm{ml}$, scales, xylazine (Xyla® Interchemie, Holland), 70\% alcohol, cotton, and EDTA tubes. Before taking radiographic images, a 
physical examination was done and giving sedatikum to the porcupine. The position of the radiograph is forelimb on the lateromedial and dorsopalmar view with the settings of $\mathrm{kVp} 50$ and mAs 6 . The data of radiographic anatomy was measured using software MicroDicom and analized by qualitative descriptive.

\section{RESULTS AND DISCUSSIONS}

Bones on radiographs will look radioopaque (white) and easily distinguishable. According to Thrall (2013) this is due to the considerable absorption of bone against $\mathrm{x}$-rays. Bone has a high calcium level and high density so that it can absorb a lot of X-ray radiation. As a result, after X-ray radiation reaches the film, the film becomes bright. Muscle tissue (soft tissue) has low calcium levels and low density so that it will absorb less X-ray radiation than bone. As a result, a lot of $\mathrm{X}$ ray radiation reaches the film and film darkens (Morow et al., 2018). In general, the radiograph of the sunda porcupine's forelimb is shown in Figure 1.

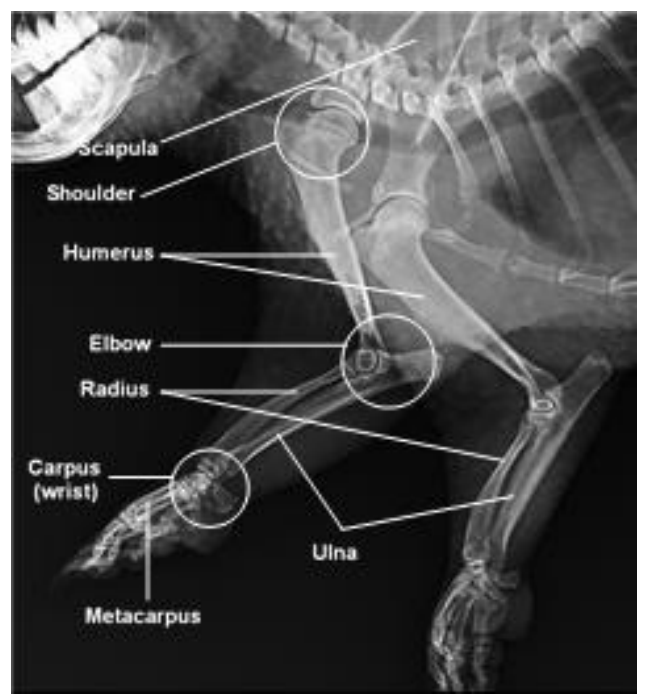

Figure 1. Latero-medial view of forelimb radiograph of the sunda porcupine.

The forelimb of the sunda porcupine include the shoulder joint, elbow joint, metacarpal, carpus, and digit. The picture of the arm radiograph of the sunda porcupine is shown in Figure 2.

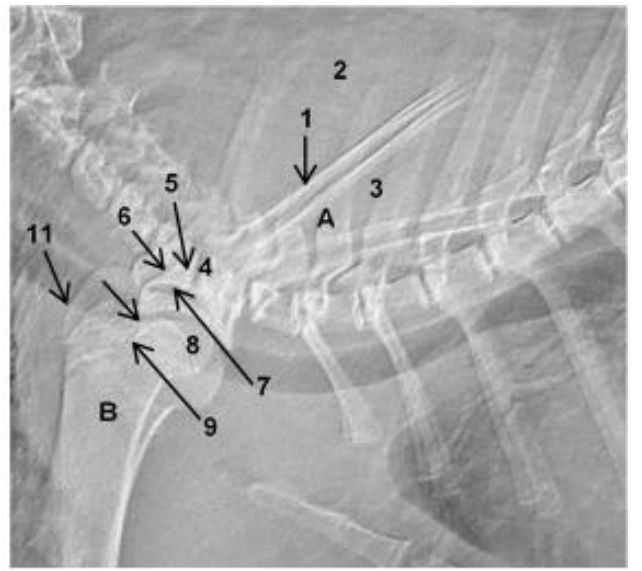

Figure 2. Latero-medial view of shoulder joint radiograph of the sunda porcupine. Scapula (A), Humerus (B), Spine of scapula (1), Supraspinous fossa (2), Infraspinous fossa (3), Acromion (4), Coracoid process (5), Supraglenoid tubercle (6), Glenoid cavity (7), Head of humerus (8), Lesser tubercle (9), Intertubercular groove (9), Intertubercular groove (10), Greater tubercle (11).

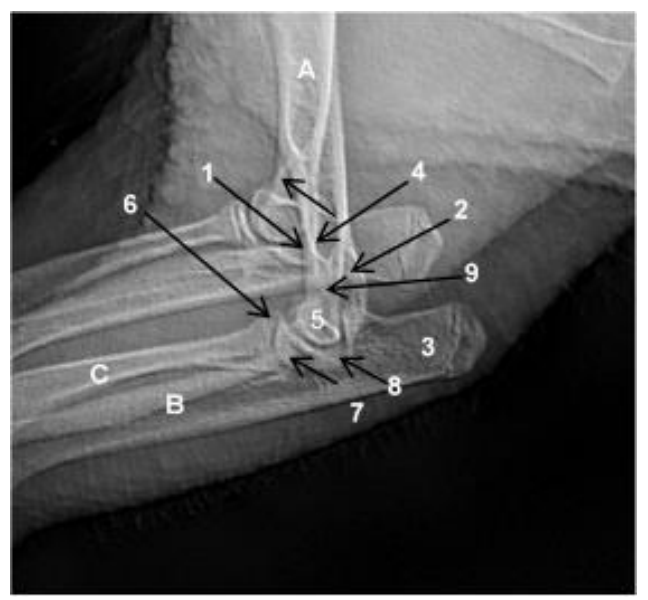

Figure 3. Latero-medial view of elbow joint radiograph of the sunda porcupine. Humerus (A), Ulna (B), Radius (C), Supracondyloid foramen (1), Lateral epicondyle (2), Olecranon (3), Olecranon fossa (4), Condyle (5), Medial coronoid process (6), Trochlea of condyle (7), Medial epicondyle (8), Anconeal process (9).

The results of radiographs of the forelimb on the lateral position of the sunda porcupine show os scapula and os humerus. Part of the os scapula consists of spine of scapula, supraspinous fossa, infraspinous 
fossa, acromion, coracoid process, supraglenoid tubercle, and glenoid cavity. While the part of the os humerus consists of the head of the humerus, lesser tubercle, and greater tubercle. The upper arm of the forelimb is directly related to the elbow joint. The elbow joint radiograph in the sunda porcupine is shown in Figure 3.

The results of radiographs of the forearm on the lateral leg of the sunda porcupine show os scapula and os humerus. While the part of the os humerus consists of the Head of the humerus, Lesser tubercle, and Greater tubercle. The upper arm of the front leg is directly related to the elbow joint. The elbow joint radiograph in the sunda porcupine is shown in Figure 4.

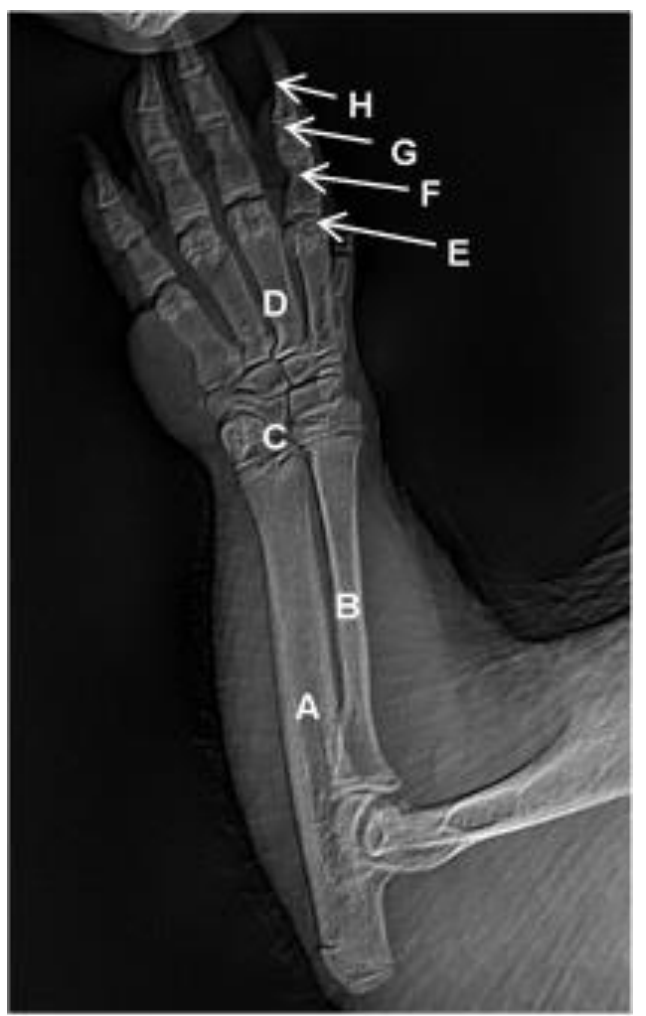

Figure 4. Dorso-palmar view of carpus, metacarpal bones and phalanges radiograph of the sunda porcupine. Ulna (A), Radius (B), Carpal (C), Metacarpal (D), Proximal phalanx (E), Middle phalanx (F), Distal phalanx (G), Ungual process $(\mathrm{H})$.

The results of radiographs of the forelimb of the sunda porcupine in the dorso-palmar view show the os ulna, os radius, os carpal, os metacarpal, os proximal phalanx, os middle phalanx, os distal phalanx, and ungual process. The forelimb has five digits with shorter thumbs.

In this research there were no artifacts on all radiographic images. Artifacts are technical errors when taking radiographic images. Artifacts can cover or resemble a clinical state and cause a decrease in the quality of radiographic results (Oestmann et al., 1991; Willis et al., 2004).

The forelimb functions not only as a locomotion tool but also for holding body weight (Sigit, 2000). The arrangement of the forefoot bones is homologous with the arrangement of the bones of the human hand, which consists of the shoulder blades (os scapula), the upper arm bone (the humerus), the bones of the forearm (os radius and ulna), the bones of the wrist (ossa carpi), bones of the palm (ossa metacarpi), finger bones (ossa phalanges I, II, III) and ossa sesamoidea proximales and distales (Sigit, 2000). Plantigradi is an animal that places its feet on the palms of the hands and soles of the feet, starting from the ossa carpi / tarsi to the toes. The number of fingers is usually five. Because the legs that support the ground are quite large, these feet can support a better weight. The animal can stand on its hindlimb and use its forelimb for other jobs, such as holding or climbing. Here the forelimb is more often called the hand (Sigit, 2000). Body movements produced by the forelimb and hindlimb allow animals to be able to forage, defend themselves, seek shelter, and make marriages (Sigit, 2000).

Beside from being plantigradi animals, porcupines are referred as fossorial animals because of their ability to make holes by digging soil for resting and sheltering during the day (Nowak, 2000). As a form of adaptation efforts in the lowlands, the sunda porcupine has good ability in digging and making holes in the ground as its nest. Olecranon process of burrowing animals indicated the index of fossorial ability (Lagaria and Youlatos, 2006). Due to fossorial animal, the activities of sunda 
porcupine in digging and making holes are also carried out as a form of adaptation in the lowlands. Porcupines make holes by digging soil in caves, rock slits, hilly areas, and terrain with diverse soil conditions. Digging activities are carried out quickly using the forelimb to decompose the soil, then the soil will be removed and removed from the excavation hole using the back foot (Feldhamer et al., 1999).

\section{CONCLUSION}

Evaluation of the results of radiographs of the front legs of the sunda porcupine in the lateral view and dorso-palmar view do not show any abnormalities. The arrangement of the forelimb bones is homologous with the arrangement of the bones of the human hand and other mammals, which consist of the scapula (os scapula), the upper arm bone (os humerus), the bones of the forearm (os radius and ulna), bone- wrist bones (ossa carpi), bones of the palms (ossa metacarpi), finger bones (ossa phalanges I, II, III) and ossa sesamoidea proximales and distales.

\section{ACKNOWLEDGMENT}

The authors would like to thank Ministry of Enviroment anf Forestry, animal ethics commision on research institution and community service (KEHLPPM) IPB has given permission to carry out research, My Vets Animal Clinic BSD South Tangerang for helping on facilities in the research and also Study Program of Animal Biomedical Science, Department of Veterinary Clinic Reproduction and Pathology, IPB University for doing the research. The author states there is no conflict of interest with the parties concerned in this research.

\section{REFERENCES}

Davies AM, Pettersson H. 2002. The WHO manual of diagnostic imaging. World Health Organization in collaboration with the International Society of Radiology, Switzerland.
Duncan JS, Singer ER, Devaney J, Oultram JWH, Walby AJ, Lester BR, Williams HJ. 2013. The radiographic anatomy of the normal ovine digit, the metacarpophalangeal and metatarsophalangeal joints. Vet. Res. Com. 37(1): 51-57.

Feldhamer GA, Lee D, Stephen V, Joseph M. 1999. Mammalogy: Adaptation, diversity, and ecology. $1^{\text {st }}$ Ed. McGrawHill Higher Education. USA.

Galateanu G, Hermes R, Saragusty J, Göritz F, Potier R., Mulot B, Maillot A., Etienne P, Bernardino R, Fernandes T, Mews J, Hildebrandt, TB. 2014. Rhinoceros feet step out of a rule-ofthumb: A wildlife imaging pioneering approach of synchronized computed tomography-digital radiography. Synch. Imag. Rhino. 9(4): 1-12.

[IQWiG] Institute for Quality and Efficiency in Health Care. Understanding test used to detect bone problems. Germany.

[KKP] Kementerian Kelautan dan Perikanan. 2015. Keputusan kepala badan karantina ikan, pengendalian mutu dan keamanan hasil perikanan No. 67/KEP-BKIPM/2015 tentang petunjuk teknis pemetaan sebaran jenis agen hayati yang dilindungi, dilarang dan invasif di Indonesia. Jakarta (ID): KKP.

Kotter E, Langer M. 2002. Digital radiography with large-area flatpanel detectors. Eur. Radiol. 12: 2562-2570.

Lagaria A, Youlatos D. Anatomical correlates to stratch digging in the forelimb of European ground squirrels (Spermophillus citellus). J. Mammal. 87(3): 563-570.

Makungu M, Groenewald, HB, Plessis, WM, Barrows M, Koeppel KN. 2013. Osteology and radiographic anatomy of the pelvis and hind limb of healthy ringtailed lemurs (Lemur catta). Anat. Histol. Embriol. 43(3): 190-202.

Mohamed R. 2018. Anatomical and radiographic study on the skull and mandible of the common opossum (Didelphis Marsupialis Linnaeus, 
1758) in the Caribbean. Vet. Sci. 5(44): $1-10$.

Morow SM, Panjaitan B, Syafruddin, Masyitha D, Erwin, Thasmi CN. 2018. Densitas radiografi tulang humerus anjing lokal (Canis lupus familiaris) yang diovariohisterektomi. JIMVET. 2(3): 304-310.

Nowak RM. 2000. Walker's mammals of the world. Int. J. Primatol. 21(3): 561563.

Oestmann JW, Prokop M, Schaefer CM, Galanski M. 1991. Hardware and software artifacts in storage phosphor radiography. Radiographics. 11(5): 795-805.

Rahmah AA, Tana S, Mardiati SM. 2017. Hematologi kelinci setelah implantasi ultra high molecular weight poliethtylene (UHMWPE) pada sendi lutut. Bul. Anat. Fisiol. 2(2): 99-106.

Schimming BC, Rahal SC, Shigue DA, Linardi JL, Vulcano LC, Teixeira CR. 2015. Osteology and radiographic anatomy on the hind limbs in marshdeer
(Blastocerus dichotomus). Pesq. Vet. Bras. 35(12): 997-1001.

Sigit K. 2000. Peranan alat lokomosi sebagai sarana kelangsungan hidup hewan: Suatu kajian anatomi fungsional. Orasi Ilmiah Guru Besar Tetap Ilmu Anatomi. Fakultas Kedokteran Hewan IPB. Bogor.

Thompson TG. 2004. Bone health and osteoporosis: A report of te surgeo general. Department of Health and Human Services, Office of the Surgeon General. US.

Thrall D, Robertson I. 2010. Atlas of normal radiographic anatomy and anatomic variants in the dog and cat. Elsevier. US.

Thrall DE. 2013. Textbook of veterinary diagnostic radiology. Elsevier Saunders. US.

Willis CE, Thompson SK, Shepard SJ. 2004. Artifacts and misadventures in digital radiography. Appl. Radiol. 33(1): 11-20. 